\title{
PEMANFAATAN PELEPAH DAUN SAWIT SEBAGAI PAKAN SUMBER SERAT: STRATEGI DAN RESPON PRODUKSI PADA SAPI POTONG
}

\author{
Wisri Puastuti \\ Balai Penelitian Ternak, POBOX 221 Bogor \\ Email: wisri_puast@yahoo.com
}

\begin{abstract}
ABSTRAK
Pakan dari lahan perkebunan berpeluang untuk pengembangan populasi sapi di Indonesia. Pemanfaatan pelepah daun sawit sebagai pakan sapi masih sangat terbatas disebabkan beberapa alasan. Pelepah daun sawit sangat potensial baik dari segi kuantitas maupun kualitas nutrisinya. Ketersediaan pelepah daun sawit sebanyak $5872 \mathrm{~kg} / \mathrm{ha} /$ tahun bahan kering mampu memenuhi kebutuhan sumber serat untuk 2 unit ternak. Bagian yang diberikan meliputi hanya daun utuh, pelepah dicacah atau pelepah dan daun dicacah. Melalui pengolahan dapat meningkatkan kadar protein kasar pelepah daun sawit menjadi 10,3-19,5\% dan kecernaan bahan kering menjadi 53,4\%. Pengolahan memperpanjang masa simpan sehingga dapat dijadikan cadangan pakan. Pemberian pelepah daun sawit hingga 55\% bahan kering ransum mampu menghasilkan PBHH sapi potong hingga $0,85 \mathrm{~kg}$. Dapat disimpulkan bahwa melalui cara yang tepat pelepah daun sawit dapat digunakan sebagai pakan sumber serat dan mendukung produksi sapi yang optimal.
\end{abstract}

Kata kunci: Sapi potong, pelepah daun sawit, sumber serat.

\section{ABSTRACT}

Feed resources from the plantation is potential to develop cattle population in Indonesia. Utilization of oil palm frond as cattle feed is very limited due to several reasons. Oil palm frond is potential as feed in terms of both quantity and quality of nutrient. Availability of oil palm frond is around $5,872 \mathrm{~kg} \mathrm{DM} / \mathrm{ha} /$ year can meet the fiber requirement for 2 animal units. Part of oil palm frond which can be used as feed include leaf, frond and whole of oil palm frond chopped or shredded. Through processing can increase the crude protein content of oil palm frond from 10.3 to $19.5 \%$ and dry matter digestibility to $53.4 \%$. Processing also extend the storing period, so it can be used as a feed stock. Giving up to $55 \%$ of the ration dry matter resulted average daily gain in beef cattle to $0.85 \mathrm{~kg}$. It is concluded that oil palm frond can be used as a feed source of fiber through the proper way and support the optimal production of cattle.

Key words: cattle, oil palm frond, source of fiber.

\section{PENDAHULUAN}

Penggembalaan sapi di kawasan perkebunan kelapa sawit telah dilakukan masyarakat yang tinggal di sekitar perkebunan. Kelimpahan biomassa di bawah/sekitar pohon sawit, terutama ketika tanaman masih muda, merupakan potensi yang sangat besar untuk menggembalakan sapi, atau ternak ruminansia lainnya (Prawiradiputra, 2009). Potensi pakan biomassa di kebun sawit sangat bervariasi tergantung dari kondisi lahan, manajemen dan umur tanaman pokok. Besarnya daya tampung berdasarkan umur tanaman sawit untuk setiap hektar per tahun adalah 1-3 tahun (1-3 ekor sapi dewasa); 4-10 tahun (0,4-0,8 ekor sapi dewasa) dan $>10$ tahun (o,6-1,0 ekor sapi dewasa) (Ginting, 1991).

Pada satu sisi sumber pakan biomassa di bawah/di sekitar tanaman sawit berlimpah, namun di sisi lain kehadiran sapi di areal kebun sawit menimbulkan kekawatiran bagi pemilik kebun. Keberadaan sapi di areal kebun kelapa sawit yang belum berproduksi, berpotensi merusak tanaman pokok, akibat dimakannya daun sawit yang masih terjangkau oleh sapi atau injakan sapi yang merusak tanaman sawit muda. Apabila pemilik kebun bukan pemilik ternak biasanya kurang senang dan bahkan melarang masyarakat menggembalakan ternak di kawasan perkebunan. Tindakan tersebut bisa dipahami karena selain merusak tanaman secara langsung, adanya ternak dikawatirkan juga dapat menyebabkan pemadatan lahan, menyebarkan jamur ganoderma, dan berpeluang menimbulkan konflik sosial (Diwyanto et al., 2013). Walau demikian kekawatiran terhadap jamur ganoderma belum sepenuhnya terbukti kebenarannya.

Potensi sumber pakan dari kebun sawit yang belum banyak dimanfaatkan adalah pelepah daun sawit. Secara periodik tanaman yang sudah menghasilkan 
(TM) tandan buah kelapa sawit dilakukan pemangkasan daun tua setiap 2-3 minggu sekali. Sebagai sumber serat, potensi pelepah daun sawit ini sangat besar dan tersedia sepanjang tahun. Dari segi kuantitas dan kualitas ketersediaan pelepah daun sawit sangat mendukung pengembangan ternak sapi di Indonesia. Pelepah daun sawit yang bentuknya besar dan keras diperlukan sentuhan teknologi agar dapat diberikan pada ternak. Beberapa penelitian pengolahan pelepah daun sawit sebagai pakan sudah banyak dilaporkan (Dahlan et al., 2000; Kawamoto et al., 2001; Pangkoeum et al., 2006; Nurhaita et al., 2008) namun aplikasi di lapang masih belum berkembang. Berdasarkan hal tersebut maka pada tulisan ini akan diuraikan strategi pemanfaatkan pelepah daun sawit dan respon pemberiannya pada ternak sapi potong. Dari tulisan ini diharapkan dapat diaplikasikan teknologi pemanfaatan pelepah daun sawit sebagai pakan sapi dari mulai yang sangat sederhana hingga dengan pengolahan dan suplementasi sehingga dapat mendukung pengembangan sapi nasional.

\section{DASAR PEMIKIRAN}

Awal mula pemanfaatan pelepah daun sawit sebagai pengganti hijauan rumput dilakukan dengan tujuan untuk mengatasi kekurangan hijauan rumput di saat jumlah sapi yang dipelihara semakin bertambah $(>1$ ekor sapi per hektar luas lahan), ketersediaan rumput di lahan sawit semakin menurun dengan meningkatnya umur tanaman pokok dan musim kemarau. Di sisi lain pelepah daun terus tersedia karena pemangkasan (pruning) yang dilakukan secara rutin. Bila dihitung pemanfaatan pelepah daun sawit dapat dimanfaatkan untuk mencukupi kebutuhan bahan kering sejumlah 7,2 juta ekor satuan ternak ( $1 \mathrm{ST}=250 \mathrm{~kg}$ ) (Puastuti et al., 2012) dengan asumsi hanya 50\% yang boleh dikeluarkan dari kebun. Potensi yang sangat besar ini baru sebagian kecil yang memanfaatkan.

Berbagai teknologi pengolahan pelepah daun sawit sudah dihasilkan dan dilaporkan mampunyai palatabilitas tinggi dan meningkatkan kecernaan bahan kering. Hasil-hasil penelitian pemanfaatan pelepah daun sawit maupun produk samping industri kelapa sawit juga sudah dilaporkan dengan hasil yang positif terhadap produktivitas ternak (Ishida et al., 1994; Wan Zahari et al., 2003; Paengkoum et al., 2006). Memperhatikan kondisi di lapang, masih sangat terbatas peternak yang memanfaatkan pelepah daun sawit sebagai sumber serat, mereka masih sangat bergantung pada hijauan rumput sehingga menimbulkan masalah pakan dengan semakin bertambahnya skala usaha. Untuk mengatasi masalah ini maka pemanfaatan pelepah daun sawit sebagai sumber pakan serat sangat perlu diterapkan.
Kemudahan dan respon positif pemanfaatan pelepah daun sawit sebagai pakan sangat perlu disosialisasikan.

\section{PEMBAHASAN}

\section{Potensi Pelepah Daun Sawit sebagai Pakan Serat}

Sumber pakan yang berasal dari produk samping perkebunan dan produk samping pengolahan minyak sawit sangat berpotensi sebagai pakan ternak. Perkebunan kelapa sawit mempunyai potensi besar sebagai penyedia pakan untuk sapi (Wan Zahari et al., 2003). Berbagai produk samping dari tanaman sawit seperti pelepah daun sawit dan batang sawit serta produk samping pabrik pengolahan buah sawit seperti tandan kosong, serat perasan sawit, bungkil inti sawit dan lumpur sawit (solid) dapat dimanfaatkan sebagai pakan sapi.

Potensi pelepah daun sawit untuk setiap hektar areal penanaman dapat dihitung sebagai berikut: Setiap hektar lahan dapat ditanami sejumlah 130-140 pohon sawit. Sebagai upaya perawatan tanaman sawit secara periodik dilakukan pemangkasan (pruning) pelepah terbawah setiap 2-3 minggu sebanyak 1-2 pelepah. Untuk setiap pohon menghasilkan rata-rata sebanyak 22 pelepah per tahun dengan rataan bobot pelepah $7 \mathrm{~kg}$ dan daun tanpa lidi $0,5 \mathrm{~kg}$ per batang (rasio pelepah : daun $=14: 1$ ). Dari jumlah tersebut dapat diperoleh $20.020 \mathrm{~kg}$ (22 pelepah x 130 pohon x $7 \mathrm{~kg}$ ) pelepah segar atau $5.214 \mathrm{~kg}$ bahan kering, dan $1.430 \mathrm{~kg}$ daun segar atau $658 \mathrm{~kg}$ bahan kering untuk setiap hektar dalam setahun (Mathius, 2009).

Produksi pelepah dan daun sawit masing-masing sebanyak $5.214 \mathrm{~kg}$ dan $658 \mathrm{~kg}$ bahan kering per hektar per tahun (total $5872 \mathrm{~kg} / \mathrm{ha} /$ tahun). Dengan perkembangan yang pesat luas perkebunan sawit saat ini mencapai 9,23 juta hektar (BPS, 2013), dengan asumsi 70\% tanaman sawit dengan status TM akan tersedia sekitar 37 juta ton bahan kering. Mengikuti persyaratan pemanfaatan biomasa pelepah sawit maksimal sebanyak 50\% yang boleh dikeluarkan dari perkebunan, maka sebanyak 18,5 juta ton dapat dimanfaatkan untuk mencukupi kebutuhan bahan kering minimal sejumlah 7,2 juta ekor satuan ternak (1 ST = $250 \mathrm{~kg}$ ) (Puastuti et al., 2012). Perkembangan yang pesat dari luasan kebun sawit menyimpan potensi besar bagi daya tampung jutaan populasi sapi dan dengan demikian merupakan harapan besar bagi lokasi pengembangan untuk meningkatkan populasi sapi potong di Indonesia (Diwyanto dan Rusastra, 2013). Pelepah dan daun sawit sebagai sumber pakan serat memiliki komposisi gizi seperti pada Tabel 1 .

Bila dibandingkan dengan komposisi rumput Gajah dengan komposisi 7,9\% protein kasar, 66,3\% serat deterjen netral (SDN), dan 46,1\% serat deterjen asam (SDA) serta energi GE sebesar $3635 \mathrm{Kkal} / \mathrm{kg}$ (Puastuti 
Tabel 1. Komposisi daun dan pelepah sawit

\begin{tabular}{|c|c|c|c|c|c|c|c|c|c|}
\hline \multirow{2}{*}{ Jenis } & \multicolumn{8}{|c|}{ Komposisi (\%) } & \multirow{2}{*}{$\begin{array}{l}\text { Energi } \\
\text { Kkal/kg }\end{array}$} \\
\hline & BK & Abu & PK & LK & SK & NDF & ADF & BETN & \\
\hline Daun sawit tanpa lidi ${ }^{1}$ & 46,2 & 13,4 & 14,1 & 4,4 & 21,5 & - & - & 46,6 & 4461 \\
\hline Pelepah sawit $^{1}$ & 26,1 & 5,1 & 3,1 & 1,1 & 50,9 & - & - & 39,8 & 4841 \\
\hline Pelepah $^{2}$ & 25,5 & 3,2 & 4,7 & 3,5 & 38,5 & 78,7 & 55,6 & - & - \\
\hline Pelepah daun sawit ${ }^{3}$ & 39,9 & 4,4 & 6,2 & 2,7 & - & 68,9 & 57,2 & - & - \\
\hline Pelepah 4 & 86,2 & 3,3 & 5,8 & 5,8 & 48,6 & - & - & 36,5 & - \\
\hline Pelepah daun sawit pelet ${ }^{5}$ & - & 5,3 & 6,3 & - & - & 67,6 & - & - & 4197 \\
\hline Pelepah tanpa kulit ${ }^{6}$ & 26,1 & 5,1 & 3,07 & 1,1 & 50,9 & - & - & 39,8 & 4841 \\
\hline
\end{tabular}

Sumber: ${ }^{1}$ Mathius (2009); ${ }^{2}$ Wong dan Wan Zahari (1992); ${ }^{3}$ Pimpa et al., (2010); ${ }^{4}$ Idris et al., (1998); ${ }^{5}$ Khamseekhiew et al., (2002); Elisabeth dan Ginting (2003)
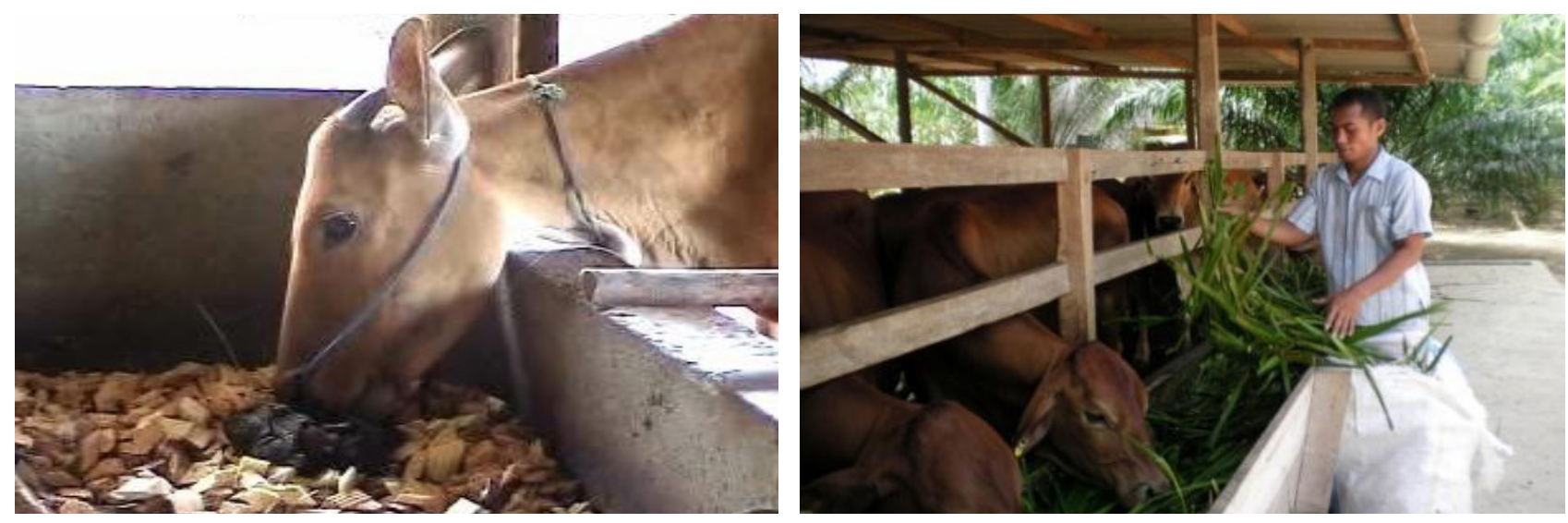

Gambar 1. Pemberian pelepah daun swawit. a. pelepah sawit yang dipotong-potong secara manual; b. daun sawit utuh

Sumber: a. Mathius PPTx; b. Koleksi pribadi

dan Yulistiani 2014) maka pelepah daun sawit secara keseluruhan memiliki kualitas yang mendekati rumput Gajah. Kecernaan in vitro dari daun sawit lebih tinggi dibandingkan dengan pelepahnya yaitu $43,52 \%$ vs $39,10 \%$ (Dahlan, 1992) dan kecernaan in vivo dari pelepah daun sawit sebesar 45,7\% Pimpa et al. (2010). Selanjutnya nilai kecernaan daun sawit sedikit lebih rendah dibandingkan dengan nilai kecernaan rumput rata-rata 50\%, namun dari segi kandungan gizinya terutama protein sedikit lebih tinggi (Puastuti et al., 2012). Untuk meningkatkan ketersediaan pelepah daun sawit diperlukan pengolahan sebelum diberikan pada ternak.

\section{Bentuk Pemberian Pakan Pelepah Daun Sawit}

Mengingat ukurannya yang besar dan bentuknya yang keras, pemberian daun kelapa sawit pada ternak harus diubah bentuk dan ukurannya untuk meningkatkan efisiensi. Pelepah daun sawit dapat diberikan dalam keadaan segar atau sudah diolah. Pada awalnya sebelum diciptakan alat pencacah yang tepat, pelepah sawit diberikan dengan cara dipotongpotong secara manual dan daunnya diberikan secara utuh (Gambar 1). Pemberian pelepah dimulai dengan cara dikupas (dihilangkan kulitnya yang keras), dibelah-belah dan dipotong-potong. Melalui adaptasi, pakan pelepah sawit mampu dikonsumsi oleh sapi dalam jumlah setara dengan hijauan rumput (Gambar 1a). Sapi mampu mengkonsumsi pelepah sawit yang dicacah sejumlah 39,7 g/kg bobot metabolis (Wong dan Wan Zahari, 1992). Palatabilitas dan konsumsi pelepah sawit dilaporkan meningkat dengan perlakuan pencacahan (Mathius et al., 2004).

Pemberian daun sawit utuh didasarkan pada insting sapi yang akan memilih bagian daun dan menyisakan lidi (sebanyak 10-15\% dari jumlah yang diberikan). Sapi akan memakan bagian ujung daun dengan lidi lemas terlebih dahulu, dan jika mengenai bagian lidi yang kaku maka akan menarik-narik daun yang dimakannya sehingga terlepas dari lidi yang kaku atau memotongnya (Gambar 1b).

Dari kajian yang dilakukan PT AGP di Provinsi Lampung dapat kesimpulan bahwa pemberian daun sawit tanpa dicacah dapat diberikan langsung kepada sapi dalam jangka panjang, tanpa memberikan pengaruh negatif pada kesehatan dan reproduksi sapi (Diwyanto et al., 2013). Pemanfaatan pelepah dan daun secara bersama-sama dapat dilakukan dengan cara dicacah halus dengan ukuran $0,5-1 \mathrm{~cm}$ (seperti abon halus) dengan bantuan alat shredder (Gambar 2a). Pemberian pelepah daun sawit seperti ini sangat bergantung keberadaan alat pencacah. Alat pencacahan pelepah daun sawit sudah dihasilkan oleh Pusat Penelitian Kelapa Sawit (PPKS) di Medan, Balai Besar Mekanisasi Pertanian (BB Mektan) dan sudah diadopsi di beberapa kelompok ternak di Riau, Jambi dan Kalimantan Selatan. Pelepah utuh yang baru dipanen langsung dapat dicacah dan menghasilkan 

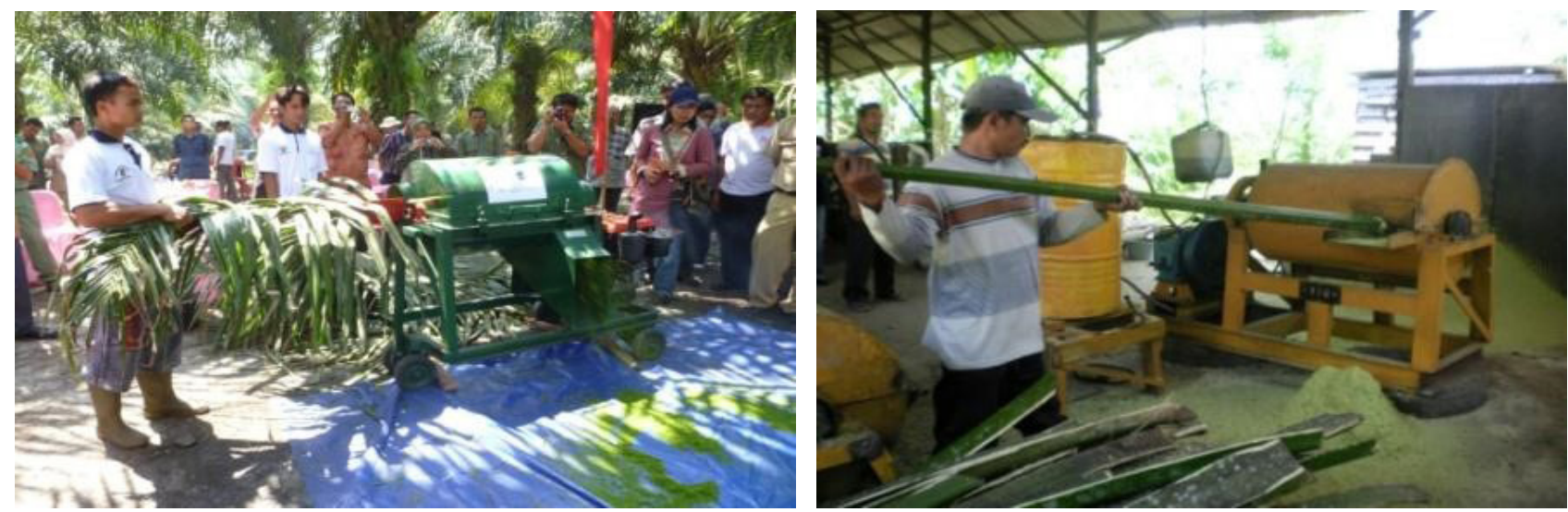

Gambar 2. Pelepah daun sawit yang dicacah dengan shredder: a. seluruhnya, b. hanya pelepahnya saja.

Sumber: a. Diwyanto PPTx (2012); b. Koleksi pribadi

cacahan halus yang homogen dan yang terpenting pada bagian lidi juga ikut halus sehingga tidak membahayakan sapi yang mengkonsumsi. Walau demikian perbedaan alat pencacah mempengaruhi hasil cacahan. Seperti yang terjadi di Kalimantan Tengah, bila mencacah seluruh pelepah daun dihasilkan cacahan dengan lidi yang tajam sehingga dikawatirkan membahayakan ternak. Untuk mengatasi hal tersebut maka yang dimanfaatkan sementara hanya pelepahnya saja (Gambar 2b).

Pemberian pelepah daun yang dicacah halus dapat memenuhi kebutuhan antara 40-60\% BK total ransum. Untuk mencukupi kebutuhan gizi masih harus diberi pakan penguat antara lain solid sawit, bungkil inti sawit, dedak padi, onggok, molases, urea dan mineral.

\section{Pengolahan Pelepah Daun Sawit Sebagai Pakan}

Pengolahan bahan pakan dengan serat kasar tinggi dapat dilakukan secara fisik/mekanik, kimiawi, biologis dan kombinasinya. Pengolahan secara fisik/ mekanik: melalui pencacahan dan pengeringan. Perlakuan secara fisik terhadap pelepah, antara lain dengan pencacahan dalam bentuk kubus sebesar 1-2 $\mathrm{cm}^{2}$ dan/ataupun penggilingan. Bisa juga dilanjutkan dengan pembuatan pelet agar dapat meningkatkan konsumsi, mempermudah penanganan, dan memperpanjang daya simpan. Walaupun bentuk pelet mampu meningkatkan kecernaan dan konsumsi, namun memerlukan biaya pengolahan. Perlakuan dengan peletisasi tidak meningkatkan nilai kecernaan pelepah, meskipun tingkat palatabilitasnya meningkat (Kawamoto et al., 2001). Oleh karena itu proses pembuatan pelet berbahan pelepah hanya disarankan untuk meningkatkan konsumsi bahan kering dan mempermudah penanganan.

Pengolahan secara kimiawi: menggunakan tambahan bahan kimia

Substrat target yang pada umumnya diberi perlakuan kimia adalah bahan dengan kandungan serat kasar yang tinggi seperti pelepah sawit. Perlakuan secara kimia dengan menggunakan $8 \%$ sodium hidroksida $(\mathrm{NaOH})$, dilaporkan dapat meningkatkan kecernaan bahan kering pelepah (Kawamoto et al., 2001). Penggunaan urea melalui proses amoniasi lebih aman untuk dilakukan dan mampu meningkatkan kadar protein kasarnya. Dengan menggunakan urea melalui proses amoniasi dapat meningkatkan kecernaan pakan serat (Van Soest, 2006). Pengolahan pelepah daun sawit secara kimiawi belum banyak diadopsi peternak. Pembuatan silase dengan penambahan urea atau molases belum memberikan hasil yang signifikan terhadap performa ternak, walaupun ada kecenderungan peningkatan nilai nutrien (Wan Zahari et al.,2003).

Pengolahan secara biologis: dengan penambahan mikroorganisme berupa kapang atau bakteri pada pelepah daun sawit, masih jarang dilakukan. Pembuatan silase pelepah dapat dilakukan dengan menambah sumber karbohidrat seperti molases untuk memacu bakteri asam laktat sehingga pelepah daun sawit menjadi awet dengan meningkatnya kondisi keasaman. Beberapa contoh hasil pengolahan pelepah daun sawit disajikan dapat meningkatkan kecernaan hingga 53,4\% (Tabel 2).

Pengolahan pelepah sawit dengan cara dikeringkan, disilase tanpa aditif, dibuat pelet dan dengan $\mathrm{NaOH}$ menghasilkan kadar protein kasar yang tidak berbeda $(4,7 \pm 0,3 \%)$ dengan palatabilitas pelet $>$ silase $>$ dikeringkan $>\mathrm{NaOH}$. Adapun tingkat kecernaan bahan kering pelepah sawit berturutturut diolah dengan $\mathrm{NaOH} 50,2 \%$, silase 44,4\%; dikeringkan 39,6\% dan dipelet 24,3\%. Bila pemberian pelepah sawit dalam bentuk mixed ration dengan proporsi $40 \%$ dari total bahan kering, dihasilkan nilai kecernaan berturut-turut diolah dengan $\mathrm{NaOH} 61,4 \%$; silase 59,4\%; dikeringkan 57,6\% dan dipelet 51,6\% (Kawamoto et al., 2001). 
Tabel 2. Perubahan komposisi dan kecernaan pelepah daun sawit setelah diolah

\begin{tabular}{|c|c|c|c|c|c|c|}
\hline Metode Pengolahan & $\begin{array}{c}\text { BK } \\
\text { (g/kg BK) }\end{array}$ & $\begin{array}{c}\text { PK } \\
\text { (g/kg BK) }\end{array}$ & $\begin{array}{c}\mathrm{BO} \\
\text { (g/kg BK) }\end{array}$ & $\begin{array}{c}\text { SDA } \\
\text { (g/kg BK) }\end{array}$ & $\begin{array}{c}\text { SDN } \\
\text { (g/kg BK) }\end{array}$ & $\begin{array}{c}\text { Kecernaan } \\
\text { BK (\%) }\end{array}$ \\
\hline \multicolumn{7}{|l|}{ Dahlan et al. (2000) : } \\
\hline Segar & 458,2 & 71,7 & 933 & 524,7 & & 46,8 \\
\hline Silase tanpa aditif & 399,5 & 103,1 & 935 & 479,9 & & 51,0 \\
\hline Silase $+5 \%$ molases & 376,6 & 138,2 & 912 & 478,7 & & 53,4 \\
\hline Pellet & 923,1 & 100,1 & 922 & 525,8 & & 52,7 \\
\hline Pellet (+ bahan lain) & 888,2 & 169,6 & 921 & 314,1 & & 60,7 \\
\hline \multicolumn{7}{|l|}{ Paengkoum et al., (2006) } \\
\hline Disteam + Urea $10 \mathrm{~g} / \mathrm{kg}$ & 841 & 74 & - & 422 & 713 & 49,9 \\
\hline Disteam + Urea $20 \mathrm{~g} / \mathrm{kg}$ & 803 & 103 & - & 418 & 716 & 51,3 \\
\hline Disteam + Urea $30 \mathrm{~g} / \mathrm{kg}$ & 857 & 134 & - & 431 & 714 & 53,1 \\
\hline Disteam + Urea $40 \mathrm{~g} / \mathrm{kg}$ & 787 & 165 & - & 426 & 717 & 49,3 \\
\hline Disteam + Urea $50 \mathrm{~g} / \mathrm{kg}$ & 758 & 195 & - & 424 & 720 & 47,3 \\
\hline \multicolumn{7}{|l|}{ Nurhaita et al., 2008} \\
\hline Amoniasi & 417,2 & 146,4 & 865,4 & 40,9 & 53,5 & 40,8 \\
\hline
\end{tabular}

Tabel 3. Pemberian pelepah daun sawit terhadap pertambahan bobot sapi potong

\begin{tabular}{|c|c|c|c|c|}
\hline $\begin{array}{c}\text { Jumlah } \\
\text { Pemberian }\end{array}$ & Bagian, pemberian/pengolahan & Bangsa Sapi & $\begin{array}{c}\text { Respon } \\
\text { PBHH }\end{array}$ & Sumber \\
\hline $33 \%$ BK ransum & Pelepah segar, dicacah & Sapi Bali & $0,34 \mathrm{~kg}$ & Mathius et al., 2004 \\
\hline $33 \% \mathrm{BK}$ ransum & Pelepah segar, potong dadu & Bali (bunting) & $0,421 \mathrm{~kg}$ & Mathius et al., 2007 \\
\hline $20-60 \%$ BK ransum & Pelepah daun sawit segar, dicacah halus & Brahman ACC & $0,850-0,610 \mathrm{~kg}$ & Sukri et al., 1999 \\
\hline $60 \%$ BK ransum & Pelepah daun sawit, dicacah halus & Sapi Bali & $0,58 \mathrm{~kg}$ & Elisabeth dan Ginting, 2003 \\
\hline $50 \%$ BK ransum & Pelepah diolah dengan urea & Brahman ACC & $0,45 \mathrm{~kg}$ & Ishida et al., 1994 \\
\hline $50 \%$ BK ransum & Pelepah disilase & Brahman ACC & $0,57 \mathrm{~kg}$ & Ishida et al., 1994 \\
\hline
\end{tabular}

\section{Respon Pemberian Pelepah Daun Sawit Pada Sapi Potong}

Hasil penelitian pemberian pelepah daun sawit sebagai pakan serat pengganti rumput pada sapi sudah dilaporkan dengan respon yang berbeda-beda pada sapi potong. Perbedaan respon disebabkan oleh jumlah pemberian, bentuk, ada tidaknya pengolahan serta kuantitas dan kualitas bahan tambahannya. Pada Tabel 3 disajikan beberapa contoh hasil penelitian pemberian pelepah daun sawit pada sapi potong.

Pemberian daun sawit utuh di peternakan PT Agro Giri Perkasa Lampung pada sapi bunting sebanyak $63 \%$ as fed $(\mathrm{BK}=25 \%)$ ditambah $4 \mathrm{~kg}$ konsentrat mengandung bungkil inti sawit tidak memiliki efek negatif baik pada induk maupun pedet yang dihasilkan. Performa pedet dalam kajian ini adalah sbb: (i) pedet disapih ketika berumur 99 hari, dengan rata-rata bobot $80 \mathrm{~kg} / \mathrm{ekor}$; (ii) rata-rata $\mathrm{ADG}$ o, $6 \mathrm{~kg} /$ hari saat penggemukan di feedlotter selama 200 hari; dan (iii) Rata-rata bobot sapi umur 299 hari sebesar $205 \mathrm{~kg} /$ ekor (Diwyanto et al., 2013). Pemberian pakan komplit yang mengandung pelepah sawit $45 \mathrm{~kg}$ dalam setiap $100 \mathrm{~kg}$ pakan as fed mengandung PK 12,6\% dan TDN 67,51\% cukup ideal untuk sapi Bali induk dan pejantan dengan performa yang bagus. Karena tidak tersedia alat timbang, dari performan eksterior sapi tampak sehat dan cukup gemuk dengan nilai
BCS 3-4, jadi ransum komplit yang disusun Poktan menghasilkan PBHH yang baik karena memiliki kandungan protein 12,6\%, energi TDN 67,51\% dan kecernaan yang tinggi (Puastuti et al., 2013). Beberapa hasil penelitian pemanfaatan pelepah dan daun sawit menghasilkan respon yang positif bahkan pemberian untuk jangka panjang tidak memberikan efek negatif. Pelepah dan daun sawit dengan palatabilitas yang tinggi mampu menjadi pakan potensial di masa depan untuk pengembangan ruminansia di daerah tropik (Dahlan, 2011).

\section{SIMPULAN}

Pemanfaatan pelepah daun sawit sebagai pakan sangat potensial baik dari segi kuantitas maupun kualitas nutrisinya. Diperlukan strategi yang tepat dalam pemanfaatan pelepah daun sawit sebagai pakan sumber serat untuk dapat mendukung produksi sapi yang optimal.

\section{DAFTAR PUSTAKA}

Badan Pusat Statistik. 2013. Statistik Indonesia. Badan Statistik Indonesia. Jakarta. http://www.bps.go.id/hasil_publikasi/SI_2013/index3.php?pub=Statistik\%20 Indonesia\%20203. Diunduh tanggal 24 Januari 2014.

Dahlan, I. 1992. The Nutritive value and utilization of oil palm 
leaves as a fibrous feed for goat and sheep. In Procceding Sixth Asian-Australasian Association of Animal Production, Animal Science Conggres on Recent Advances in Animal Production. Vol. III. AHAT, Bangkon, p. 271.

Dahlan, I. 2011. Oil palm frond, a feed for herbivores. AsianAus. J. Anim. Sci. Supplement. 13: 300-303.

Dahlan, I., M. Islam and M. A. Rajion. 2000. Nutrient intake and digestibility of fresh, ensiled and pelleted oil palm (Elaeis guineensis) frond by goats. Asian-Aus. J. Anim. Sci. 13 (10): 1407-1413.

Diwyanto K, R. H. Matondang dan E. Handiwirawan. 2013. Perkembangan sistem integrasi sawit-sapi di beberapa lokasi mendukung program swasembada daging sapi. Bunga Rampai. Tiesnamurti B, M. Husein Sawit, DS. Damardjati, R. Thahir (Ed.). Model Pengembangan Sistem Integrasi Tanaman-Sapi Berbasis Inovasi. ISBN. 978-602-152072-7. IAARD Press.

Diwyanto K. dan I. W. Rusastra. 2013. Pemberdayaan peternak untuk meningkatkan populasi dan produktivitas sapi potong berbasis sumber daya lokal. Pengembangan Inovasi Pertanian 6(3):105-118.

Elisabeth, J. dan S. P. Ginting. 2004. Pemanfaatan Hasil Samping Industri Kelapa Sawit Sebagai Bahan Pakan Ternak Sapi Potong. In: Sistem Integrasi Kelapa SawitSapi. Prosiding Lokakarya Nasional. Dept. Pertanian, Pemda Prov. Bengkulu dan PT Agricinal. Bengkulu. p 110-119

Ginting S. P. 1991. Keterpaduan ternak ruminansia dengan perkebunan. I. Produksi dan nilai nutrisi vegetasi perkebunan sebagai hijauan pakan. J. Penelitian dan Pengembangan Pertanian X(1):1-8.

Idris Moh. S., A. F. Mohamad dan D. Ismail. 1998. Utilization of oil palm by-products as livestock feed. In: Proc. National Seminar on Livestock and Crop Integration in Oil Palm: - Towards Sustainabilit. A. Daru, M.T. Dolmat dan S. Ismail (Eds). 12-14 May 1998, Johor-Malaysia.

Ishida, M., O. Abu Hassan, T. Nakui and F. Terada. 1994. Oil palm fronds as ruminant feed. Newsletter for international Collaboration. 2:1.

Kawamoto, H., W. Z. Mohamed, N. I.Mohd. Shukur, M. S. Mohd Ali, Y. Ismail, and S. Oshio. 2001. Palatability, digestibility, and voluntary intake of processed oil palm frond in cattle. JRQ. 35(3):195-200.

Khamseekhiew, B. J. B. Liang, Z. A. Jelan and C. C. Wong. 2002. Fibre degradability of oil palm frond pellet, supplemented with Arachis pintoi in cattle. Songklanakarin J. Sci. Technol. 24(2): 209-216.

Mathius, I. W., A. P. Sinurat, D. P. Tresnawati, dan B. P. Manurung. 2007. Suatu kajian pakan siap saji berbasis produk samping industri kelapa sawit untuk sapi bunting. Prosiding. Seminar Nasional Peternakan dan Veteriner, Pusat Penelitian dan Pengembangan Peternakan. Bogor. Hlm. 51-59.

Mathius, I. W., Azmi, B. P. Manurung, D. M. Sitompul, dan E. Priyatomo. 2004. Integrasi Sapi Sawit: Imbangan pemanfaatan produk samping sebagai bahan dasar pakan. Di dalam: Haryanto B, Mathius IW, Prawiradiputra BR, Lubis D, Priyanti A, Djajanegara A, penyunting. Prosiding Seminar Nasional Sistem Integrasi Tanaman-
Ternak. Denpasar, 20-22 Juli 2004. Bogor (ID): Puslitbang Peternakan bekerjasama dengan Balai Pengkajian Teknologi Pertanian (BPTP) Bali dan Crop Animal System Research Network (CASREN), Bali. hlm. 439-446.

Mathius, I. W. 2009. Produk samping industri kelapa sawit dan teknologi pengkayaan sebagai bahan pakan sapi yang terintegrasi. Dalam: Sistem Integrasi Ternak Tanaman: Padi-Sawit-Kakao. Pusat penelitian dan Peternakan. Badan Penelitian Pertanian. Hal. 65-109.

Nurhaita, N. Jamarun, R. Saladin, L. Warly dan Z. Mardiati. 2008. Efek suplementasi mineral sulfur dan pospor pada daun sawit amoniasi terhadap kecernaan zat makanan secara in vitro dan karakteristik cairan rumen. J.Indon. Trop.Anim.Agric. 33 (1): 51-58.

Paengkoum P, J. B. Liang, Z. A. Jelan and M. Basery. 2006. Utilization of Steam-treated Oil Palm Fronds in Growing Goats:1. Supplementation with Dietary Urea. AsianAust. J. Anim. Sci. 19(9):1305-1313

Pimpa O, Khamseekhiew B., B. Pimpa and S. Ruengsuwan. 2010. Protein requirements of beef cattle fed palm oil by-products in the South-Thailand. Khon Kaen Agr. J. 38(suplement) : 158-163

Prawiradiputra, B. 2009. Masih adakah peluang pengembangan integrasi tanaman dengan ternak di Indonesia? Wartazoa 19:143-149.

Puastuti W, E. Handiwirawan dan K. Diwyanto. 2013. Perkembangan sistem integrasi sawit-sapi di Kelompok Tani Subur Makmur Provinsi Kalimantan Tengah: Pola pemeliharaan sapi secara intensif. Bunga Rampai. B. Tiesnamurti, M. Husein Sawit, DS. Damardjati, R.Thahir (Ed.). Model Pengembangan Sistem Integrasi Tanaman-Sapi Berbasis Inovasi. ISBN. 978-602-152072-7. IAARD Press.

Puastuti W. dan D. Yulistiani. 2014. Suplemen urea dan tepung ikan dalam ransum berbasis kulit buah kakao: Evaluasi neraca nitrogen. Prosiding Seminar Nasional Peternakan - Biosource LIPI. In press

Puastuti, W., Setiadi B., dan K. Diwyanto. 2012. Strategi pemanfaatan biomas perkebunan sawit dan produk samping industri sawit sebagai sumber pakan untuk pengembangan sapi potong di perkebunan sawit. Di dalam: Tiesnamurti B, Inounu I (Penyunting). Inovasi Pengembangan Sapi Sistem Integrasi Sapi Sawit. Jakarta (ID): IAARD Press. hlm. 114158

Sukri, M., I. O. M. Arief, O. Atil and D. A. Khusairi. 1999. The effect of oil palm by products based ration on growth, carcass characteristics and quality of beef cattle in feedlot. MARDI-PORIM Project Report. p. 10.

Wan Zahari M, O. A. Hassan, H. K.Wong, and J. B. Liang. 2003. Utilization oil palm frond-based diet for beef cattle production in Malaysia. Asian-Aust J Anim Sci. 16(4):625-634

Wan Zahari, M. and Alimon, A. R. (2005). Use of palm kernel cake and oil palm by-products in compound feed. Palm Oil Developments 40. Malaysian Palm Oil Board. pp:5 - 8.

Wong, H. Kand M. Wan Zahari. 1992. Oil palm by products as animal feed. Proceedings of th MASP Ann. Conf. Kuala Trengganu pp. 58-61. 